\title{
NEW REFINEMENTS OF GENERALIZED HÖLDER'S INEQUALITY AND THEIR APPLICATIONS
}

\author{
Jing-FEng Tian AND Witold PEDRYCZ
}

Abstract. In this paper, we present a series of sharpened versions of generalized Hölder's inequality. As an application in information theory, we give a new refinement of Singh's inequality with respect to the 'useful' information of order $\alpha$ for the power distribution. The Singh's inequality include Shannon's inequality as a special case.

Mathematics subject classification (2010): 26D15, 94A17.

Keywords and phrases: Hölder's inequality, information theory, Singh's inequality, Shannon's inequality, information measure.

\section{REFERENCES}

[1] S. Abramovich, J. PeČArić And S. Varošanec, Sharpening Hölder's and Popoviciu's inequalities via functionals, Rocky Mt. J. Math., 34, 3 (2004), 793-810.

[2] S. Abramovich, J. PeČArić And S. VARošAneC, Continuous sharpening of Hölder's and Minkowski's inequalities, Math. Inequal. Appl., 8, 2 (2005), 179-190.

[3] H. Agahi, Y. Ouyang, R. Mesiar, E. Pap and M. Štrboja, Hölder and Minkowski type inequalities for pseudo-integral, Appl. Math. Comput., 217, 21 (2011), 8630-8639.

[4] E. F. Beckenbach And R. Bellman, Inequalities, Springer-Verlag, Berlin, 1961.

[5] L. L. CAMPBell, A coding theorem and Rényi's entropy, Inform. Contr., 8, 65 (1965), 423-429.

[6] J. A. Carroll, R. Cordner and C. J. A. Evelyn, A new extension of Hölder's inequality, Enseignement math., 16, (1970), 69-71.

[7] A. Feinstein, Foundation of Information Theory, McGraw-Hill, New York, 1958.

[8] J. L. W. V. JENSEN, Sur les fonctions convexes et les inégalités entre les valeurs moyennes, Acta Math., 30, 1 (1906), 175-193.

[9] B. LIU, Random fuzzy dependent-chance programming and its hybrid intelligent algorithm, Inform. Sciences, 141, 3 (2002), 259-271.

[10] J. MatKowsKi, A converse of the Hölder inequality theorem, Math. Inequal. Appl., 13, 1 (2009), $21-32$.

[11] R. J. MCeliece, The Theory of Information and Coding, Cambridge University Press, Cambridge, 2002.

[12] D. S. MitrinoviĆ AND J. E. PeČARIĆ, On an extension of Hölder's inequality, Bollet. dell'Unione Mat. Italiana, 4-A, 7 (1990), 405-408.

[13] D. S. Mitrinović, J. E. PeČARIĆ And A. M. Fink, Classical and New Inequalities in Analysis, Kluwer Academic, Dordrecht, 1993.

[14] L. NiKOLOVA AND S. VAROŠANEC, Refinements of Hölder's inequality derived from functions $\psi_{p, q, \lambda}$ and $\phi_{p, q, \lambda}$, Ann. Funct. Anal., 2, 1 (2011), 72-83.

[15] Y. OuYAng, R. Mesiar And H. Agahi, An inequality related to Minkowski type for Sugeno integrals, Inform. Sciences, 180, 14 (2010), 2793-2801.

[16] A. RenYI, On measures of entropy and information, Proc. Fourth Berkeley Symp. on Math. Statist. and Prob., 1, (1961), 547-561.

[17] C. E. Shannon, A mathematical theory of communication, Bell System Technical Journal, 27, 3 (1948), 379-423. 
[18] R. P. Singh, RajeEv Kumar And R. K. Tuteja, Application of Hölder's inequality in information theory, Inform. Sciences, 152, (2003), 145-154.

[19] J.-F. TIAN, Reversed version of a generalized Aczél's inequality and its application, J. Inequal. Appl., 2012, (2012), 202.

[20] J.-F. TiAn, Property of a Hölder-type inequality and its application, Math. Inequal. Appl., 16, 3 (2013), 831-841.

[21] J.-F. TIAN AND X.-M. Hu, Refinements of generalized Hölder's inequality, J. Math. Inequal., 7, 4 (2013), 701-710.

[22] P. M. VASIĆ AND J. E. PEČARIĆ, On the Jensen inequality for monotone functions, An. Univ. Timişoara Ser. Şt. Matematice, 17, 1 (1979), 95-104.

[23] S. Wu And L. Debnath, Generalizations of Aczél's inequality and Popoviciu's inequality, Indian J. Pure Ap. Mat., 36, 2 (2005), 49-62. 